\title{
LATE NINETEENTH CENTURY BUTTERFLY COLLECTORS IN SASKATCHEWAN
}

\author{
C. STUART HOUSTON, 863 University Drive, Saskatoon, SK S7N 0J8 and \\ BERNIE GOLLOP, 2202 York Ave., Saskatoon SK S7J 1J1
}

The first resident butterfly collector of whom we have record in present Saskatchewan is "Miss F.M. Pierce, of Moose Mountain, N.W.T." Frances "Frankie" Michell Pierce was one of eight children of Captain Edward Michell Pierce, the organizer (in 1882) of the upscale British settlement, Cannington Manor, northwest of present Redvers, Saskatchewan, complete with tennis courts, foxhounds, fox hunts, and an agricultural college. Frankie collected insects, including a Variegated Fritillary, in 1884 (FP in Table 1), and forwarded them to C.J.S. Bethune in Toronto. ${ }^{1}$

On 8 November 1885, Frankie was the first bride married in the first church consecrated in the Anglican Diocese of Qu'Appelle - All Saints Church at Cannington. Frankie married Samuel Spencer Page, 1857-1916, the first teacher and later first Member of the Legislative Assembly for the new constituency of Cannington in the North West Territories Legislative Assembly, 1891-1894 and 18941898, and first Clerk of the Legislative Assembly. ${ }^{6}$

Later in the 1880 s, probably in 1887 , Cora $E$. Rose and her two little sons collected 30 kinds of butterflies, and sent them to Henry Skinner, M.D., of Philadelphia. In her covering letter, Cora described the location of her farm as "30 miles north of an old Hudson [sic] Bay Post called Fort Qu'Appelle; the only foliage is willow and poplar." One of the butterflies Cora collected was at that time thought to represent the type specimen for a new subspecies of the Common Alpine, Erebia epipsodea sineocellata. ${ }^{7}$

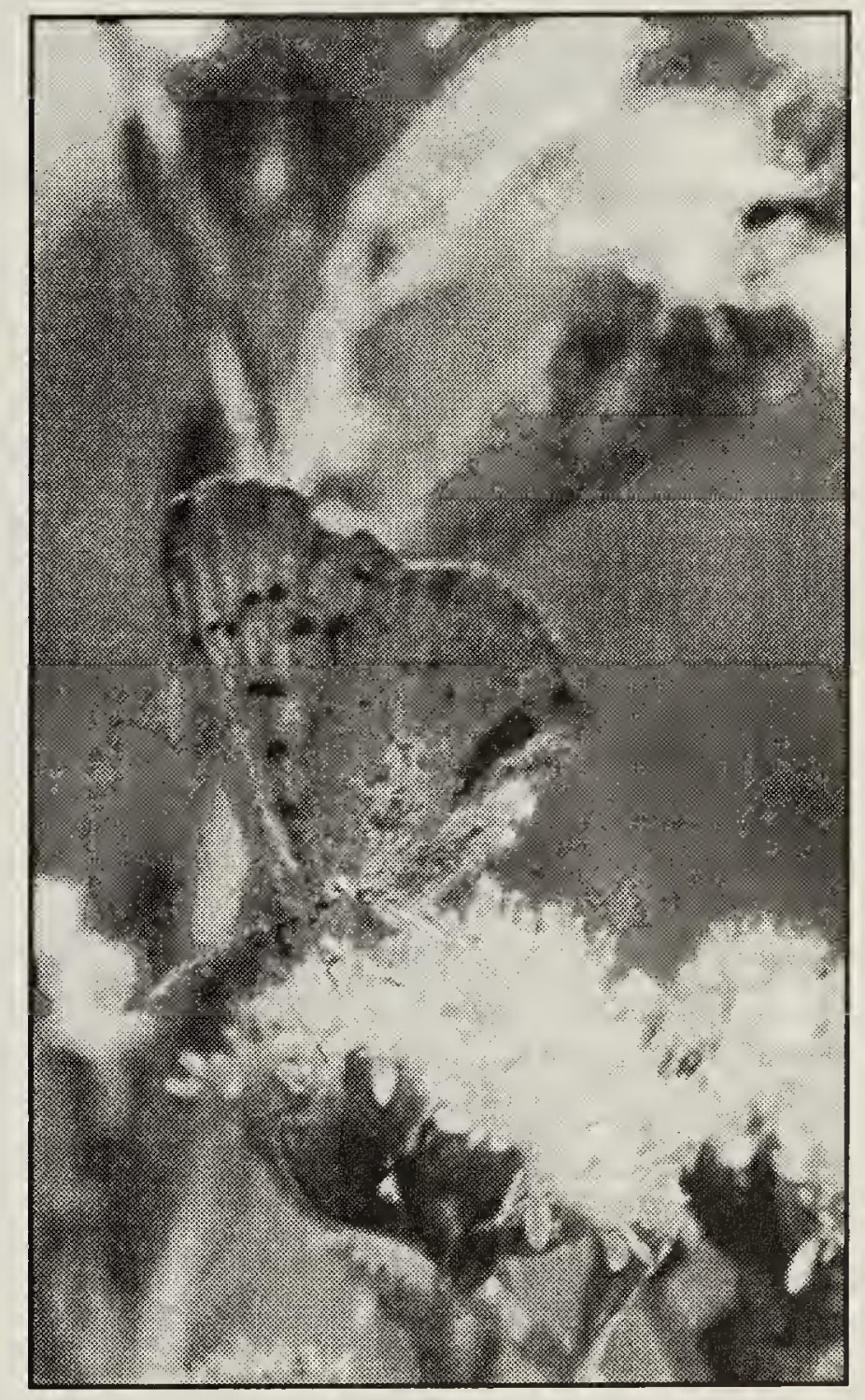

Purplish Copper on Stiff Goldenrod near Saskatoon

Photo by Anna Leighton

Cora's husband, Robert J. Rose, had homesteaded on the southwest corner of section 18 , township 24 , range 11 , west of the second meridian, and built a small shanty there in 1883 . He broke 12 acres that year, 3 the next and nearly 11 the third summer. This land is today a mile west of Highway 310,7 miles south and almost 2 miles west of Ituna, or 20 miles north and 11 miles east of Fort 
Qu'Appelle. Cora and their two children did not move from Fort Qu'Appelle onto their farm until 28 September 1886 . The 29 species/ varieties collected by Cora Rose are listed as CR in Table 1.

In 1883, about four years before Cora Rose began her collections, a collector from Toronto, Gamble Geddes, aide-de-camp to the Lieutenant-Governor of Ontario, came through in 1883 on the new Canadian Pacific Railroad. He collected briefly at Brandon on 10 June, then took a side-trip north to Fort Ellice (Hudson's Bay Company post 9 miles east of the present Saskatchewan boundary near where St. Lazare, Manitoba, is today), on 12 June, where he collected Common Checkered Skipper, then considered rare, as well as Common Alpine, Summer Azure, Silvery Blue, Meadow Fritillary, Garita Skipper, Northern Cloudywing, and Sleepy Duskywing. He also visited Fort Qu'Appelle, where he collected an Arctic Blue; Moose Jaw, where he collected an Orange Sulphur and a Western Branded Skipper; and Swift Current. Somewhere in Saskatchewan he took what is now known to be simply a Silvery Blue, but which W.H. Edwards described as a new species, Lycaena afra. Then Geddes went on to Medicine Hat (at that time in the postal district of Assiniboia) on 15 June, and Calgary on 30 June. He made a side trip north to Edmonton on 8 July, returned to Fort Macleod on 23 July, Pincher Creek on 25-30 July, then west to Garnett Ranch at the eastern end of the Crow's Nest Pass on 8 August, and Belly River on 15 August. $^{3}$

In 1884, Geddes returned once more from Toronto, leaving Winnipeg on 29 June, reaching Swift Current on 1 July (where he collected a Gray Copper and Edwards', Callippe, and Variegated Fritillaries), and Calgary on 3-7 July. ${ }^{4}$ (See GG in Table 1).

Another itinerant collector was H.H. Lyman of Montreal who stopped for a day in Regina, 5 August 1890, and collected what he felt was a new variety of Plains Skipper, Pamphila manitoba, for which he wished to give a subspecific or variety name of "assiniboia." ${ }^{5}$ (See HL in Table 1).

Two other collectors are known from single specimens. George M. Dawson, with the British North America Boundary Commission, collected an Aphrodite Fritillary at Wood Mountain, presumably in late June $1874 .^{2}$ (See GD it Table 1). N.H. Cowdry collected an Anise Swallowtail at Regina, probably between 1882 and $1895^{2}$ (see NC in Table 1).

These six amateur lepidopterists received recognition in print. We have no way of knowing whether other early butterfly collections were destroyed or found their way at least temporarily into local museums. Gollop would appreciate anyone with information about such collections contacting him at the address above.

\section{Acknowledgements}

We thank the late Lloyd Rodwell, Saskatchewan Archives, for many courtesies, and Mary Houston for making photocopies of relevant articles.

1. BETHUNE, C.J.S. 1885. Euptoieta claudia, Editor's note. Can. Entomologist 17:60.

2. EDWARDS, W.H. 1897. Butterflies of North America. Houghton Mifflin, Boston.

3. GEDDES, G. 1883,1884 . List of diurnal lepidoptera collected in the North-west Territory and the Rocky Mountains. Can. Entomologist 15:221-223; 16:56-57.

4. GEDDES, G. 1889. Notes for collectors visiting the prairies and Rocky Mountains. Can. Entomologist 21:57-58.

5. LYMAN, H.H. 1892. Pamphila manitoba Scud., and its varieties. Can. Entomologist 24:57-59.

6. PIERCE, LILY. 1924. The settlement of Cannington Manor, vol. 2, pp. 787-792, In: John Hawkes, The Story of Saskatchewan and its People (S.J. Clarke, Chicago).

7. SKINNER, H. 1889. Butterflies at Qu'Appelle, Assiniboia. Can. Entomologist 21:238-240. 
Table 1. BUTTERFLIES COLLECTED IN SASKATCHEWAN BEFORE 1895 (in taxonomic order)

1870s-1880s

Scientific Name

Eudamus pylades

Nisoniades icelus

Thanaos brizo

Pamphila manitoba

Amblyscirtes tessallata

Thymelicus garita

Pamphila idaho

Pamphila cernes

Papilio cipris

Papilio rutulus

Pieris protodice

Colias philodice

Colias eurytheme

Colias christina

Colias scudderi

Chrysophanus dione

Chrysophanus florus

Chrysophanus helloides

Lycaena neglecta

Lycaena lygdamas

Lycaena afra

Lycaena scudderii

Lycaena rustica

Euptoieta claudia

Argynnis cipris

Argynnis edwardsii

Argynnis nevadensis

Argynnis lais

Argynnis bellona

Melitea carlota

Grapta progne

Vanessa antiopa

Vanessa milberti

Pyrameis cardui

Limenitis arthemis

Coenonympha typhon

Satyrus Var. boopis

Satyrus Var. olympus

Erebia discoidalis

Erebia epipsodea

Erebia epipsodea

sine-ocellata

Chionobas varuna

Danaus plexippus
Current English Name

Northern Cloudywing

Dreamy Duskywing

Sleepy Duskywing

Common Checkered Skipper

Common Checkered Skipper

Garita Skipperling

Western Branded Skipper

Tawny-edged Skipper

Anise Swallowtail

Western Tiger Swallowtail ${ }^{*}$

Checkered White

Clouded Sulphur

Orange Sulphur

Christina Sulphur

Giant Sulphur

Gray Copper

Purplish Copper

Purplish Copper

Summer Azure

Silvery Blue

Silvery Blue

Northern Blue

Arctic Blue

Variegated Fritillary

Aphrodite Fritillary

Edwards' Fritillary

Callippe Fritillary

Northwestern Fritillary

Meadow Fritillary

Gorgone Checkerspot

Gray Comma

Mourning Cloak

Milbert's Tortoiseshell

Painted Lady

White Admiral

Common Ringlet

Common Wood-Nymph

Common Wood-Nymph

Red-disked Alpine

Common Alpine

Common Alpine

Uhler's Arctic

Monarch

\section{Collector Current Scientific Name}

GG Thorybes pylades

CR Erynnis icelus

GG Erynnis brizo

$\mathrm{CR}, \mathrm{HL}$ Pyrgus communis

GG Pyrgus communis

$\mathrm{CR}, \mathrm{GG}$ Oarisma garita

GG Hesperia colorado

CR Polites themistocles

NC Papilio zelicaon

CR Papilio rutulus

CR Pontia protodice

CR No change

CR, GG No change

CR No change

CR Colias gigantea

$\mathrm{GG} \quad L y c a e n a$ dione

CR Lycaena helloides

CR . Lycaena helloides

GG Celastrina neglecta

GG Glaucopsyche lygdamus

GG Glaucopsyche lygdamus

CR Lycaeides idas

GG Agriades glandon

FP,CR, GG No change

GD Speyeria aphrodite

GG Speyeria edwardsii

GG Speyeria callippe

CR Speyeria hesperis

CR, GG Boloria bellona

CR Chlosyne gorgone

CR Polygonia progne

CR Nymphalis antiopa

CR Nymphalis milberti

CR Vanessa cardui

CR No change

CR Coenonympha tullia

CR Cercyonis pegala

CR Cercyonis pegala

CR No change

GG No change

CR Erebia epipsodea freemani

CR Oeneis uhleri

CR No change

CR: Cora E. Rose; FP: Frances M. Pierce; GD: George M. Dawson; GG: Gamble Geddes; HL: H.H. Lyman; NC: N.H. Cowdry

* Probably Canadian Tiger Swallowtail, Papilio canadensis 


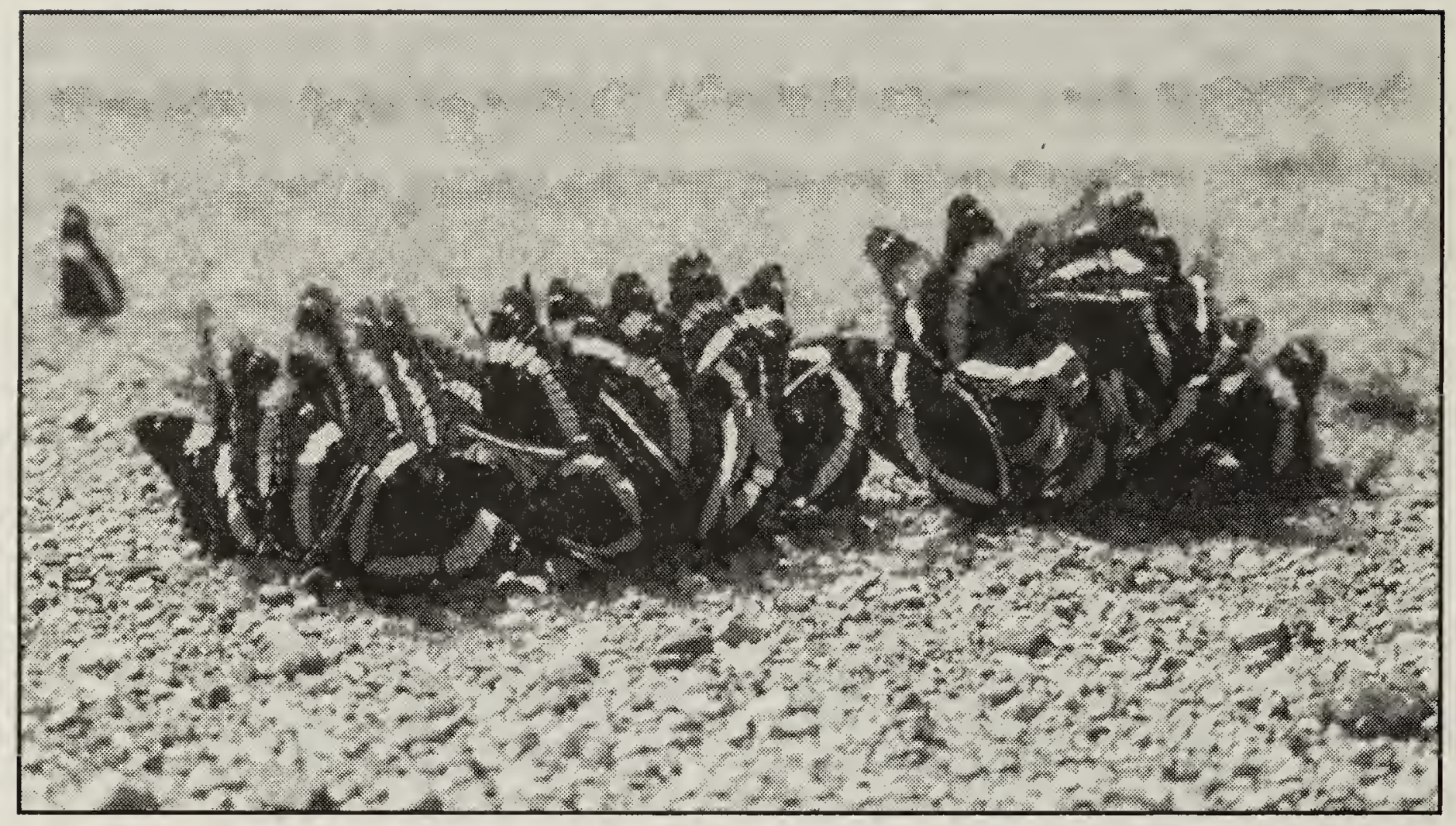

White Admirals on faeces

Photo by Chris Adam

Many species of blues [butterflies] have evolved symbiotic (mutually beneficial) relationships with ants. This usually consists of the caterpillars exuding a sweet substance known as honeydew, which is then taken up eagerly by the ants. The ants are thought to provide some protection from arthropod predators such as beetles to the sweet-bestowing larvae.

Canada's only records of Southern Cloudywing, Poweshick Skipperling, Ottoe Skipper, Dakota Skipper, Gulf Frittillary and Mexican Fritillary (Butterflies) are all from Manitoba.

Nothing is known of the history of a specimen of a Lace-winged Roadside Skipper in the Royal Saskatchewan Museum of Natural History or its collector, W.D. Leathers. 